\title{
Inovasi E-Gelang Sebagai Alat Deteksi Dini Untuk Meminimalisasi Penyebaran Covid-19
}

\author{
Sukma Rahmawati ${ }^{1)}$, Eko Purwanto ${ }^{2)}$ \\ ${ }^{1)}$ Sistem Informasi, ${ }^{2}$ Teknik Informatika \\ ${ }^{1,2}$ Universitas Duta Bangsa Surakarta Jl. Bhayangkara No.55 \\ E-mail : ${ }^{1}$ sukma_rahmawati@fikom.udb.ac.id, ${ }^{2}$ eko_purwanto@Udb.ac.id
}

\begin{abstract}
In 2020, there was a disease that horrified the world. Where pneumonia resembles, this disease originates from a virus similar to coronavirus and is called Covid-19. Covid-19 was received from Wuhan, China. Spread throughout the world and mostly for locking to break the Covid-19 distribution chain. Therefore, this paper was made to submit opinions about ideas put forward on the e-bracelet system as a Covid-19 early detection device connected to a smartphone application to see the results of its detection testing. Reference to early detection of Covid-19 presence of body temperature sensors, distance and heart rate. The method of use of this paper is the method of library study and the existence of a design system called the prototyping method. Literature study is carried out by gathering information relevant to topics that are the object of research from books, scientific papers, theses, dissertations, and journals, while the prototype used is development before leading to actual large / scale production. The results will be obtained is proof of our acceptance, our heart rate is not normal, can know our distance from the crowd is not controlled. And this e-bracelet is designed so that when 2 or more e-bracelet at the same place when it is turned on, the continuity will be notify on the application interface handphone. Mild symptoms of Covid-19 are, dry throat, sudden shortness of breath, loss of acuity of smell. The way to avoid this is by diligently washing hands, carrying hands, adhering to health protocols. The idea of converting this bracelet as an early detection of Covid-19 symptoms which can measure body temperature, distance, and heart rate as a reference to support from the self that is issued.
\end{abstract}

\begin{abstract}
Abstrak
Di tahun 2020, muncul sebuah penyakit yang menghebohkan dunia. Dimana mirip pneumonia, penyakit ini berasal dari virus yang sejenis dengan coronavirus dan disebut Covid-19. Covid-19 berasal dari Wuhan, China. Hingga menyebar ke seluruh dunia dan hampir semua menerapkan untuk lockdown agar memutus rantai penyebaran Covid-19. Oleh karena itu, karya tulis ini dibuat untuk mengusulkan gagasan ide merancang suatu sistem e-gelang sebagai alat deteksi dini Covid-19 yang terkoneksi dengan aplikasi smartphone untuk melihat hasil pengukuran deteksi nya. Acuan pada deteksi dini Covid-19 adanya sensor suhu tubuh, jarak dan jetak jantung.

Penggunaan method dari karya tulis ini adalah metode studi kepustakaan dan adanya sistem perancangan yang disebut metode prototyping. Studi kepustakaan dilakukan dengan menghimpun informasi relevan topik yang menjadi objek penelitian dari buku-buku, karya ilmiah, tesis, disertasi, dan jurnal, sedangkan prototype yaitu tahap pengembangan sebelum menuju produksi besar/skala yang sebenarnya.

Hasil yang akan didapat adalah adanya bukti suhu badan kita, detak jantung kita normal tidak, mengetahui control jarak kita dengan keramaian. Dan e-gelang ini juga dirancang agar ketika ada 2 e-gelang yang sama atau lebih bertemu ketika sudah power on, kesinambungan itu akan memberi notice pada ada interface aplikasi di handphone.

Covid-19 memiliki gejala-gejala ringan yaitu tenggorokan kering, batuk, sesak napas tibatiba, hilangnya ketajaman indra penciuman, dan lain-lain. Cara pencegahannya adalah dengan rajin mencuci tangan, membawa handsanitazer, menaati protokol kesehatan. Gagasan inovasi penciptaan gelang ini sebagai alat pendeteksi dini gejala Covid-19 yang mana bisa mengukur suhu tubuh, jarak, dan detak jantung sebagai acuan untuk mendeteksi dari dalam diri dahulu.
\end{abstract}

Kata Kunci:Pnemounia, E-Gelang, covid-19, deteksi dini 


\section{PENDAHULUAN}

Pada awal tahun 2020, dunia dihebohkan dengan adanya penyakit yang menyerang saluran pernapasan, hampir mirip dengan pneumonia. Pneumonia sendiri menyebabkan peradangan pada kantung udara di paru-paru. Saat Covid-19 berjalan, yang pertama akan merusak sel dalam saluran atas pernapasan, hal yang timbul adalah rasa gatal dan tenggorokan kering, lalu akan masuk ke saluran paru-paru yang bisa jadi merusak jaringan-jaringan yang ada didalamnya, inilah yang menyebabkan bisa terjadi sesak napas. Saat sudah timbul sesak napas atau gejala kea rah berat, harus segera ditangani oleh tim medis, karena bisa sangat berbahaya untuk semua sel dalam diri sang pengidap Covid-19. Pengertian Covid-19 sendiri adalah virus yang menyebabkan penyakit, dan virus itu bisa disebut virus SARS-CoV-2 atau Severe Acute Repiratory Syndrome Coronavirus-2 [1]. Berita Covid-19 masuk di Indonesia terkonfirmasi pertama kali pada hari Senin, 2 Maret 2020 oleh Presiden Jokowi yang menberi pengumuman ada dua orang positif terkena Covid-19, dua perempuan yakni berusia 31 tahun dan ibu-ibu umurnya sudah 64 tahun[2].

Covid-19 ini diyakini menular melalui bersin dan batuk dari satu orang ke orang lainnya. Percikan liur dari bersin atau batuk dapat menempel pada benda-benda mati yang kemudian bersentuhan dengan kita seperti dudukan toilet, barang, dll. Orang yang sudah tua atau sudah lansia menjadi orang yang paling rentan terserang Covid-19, karena imun yang sudah turun dan juga semua jaringan yang sudah melemah karena penuaan. Maka itulah sebabnya lansia bisa dikatakan yang paling rentan terserang, bisa jadi juga sulit untuk melawan berbagai jenis bakteri atau virus tidak hanya Covid-29. Padahal untuk pencegahannya jika mau menerapkan dalam keseharian yaitu diantaranya rajin cuci tangan, menggunakan masker selalu, mau untuk diam di rumah, dan membawa handsanitazer jika bepergian. Terpantau dari Data Worldometers sudah ada berkisar 3.154.259 pasien yang positif Covid-19 di seluruh dunia, data ini per 29 April 2020[3].

\section{METODE PENELITIAN \\ a. Jenis dan Sumber Data}

1) Sumber data sekunder

Artinya sumber dari semua data disini adalah buku literature, catatan, atau arsip yang pernah ada baik yang terpublikasikan maupun belum terpublikasikan. Di karya tulis ini penulis menggunakan beberapa jurnla yang membahas mengenai Covid-19 dan pengendalian atau cara meminimalisasinya. Jenis data ini adalah deskriptif kualitatif, yang mana menjelaskan fakta-fakta keadaan yang tampak mengenai Covid-19 dengan sebenarbenarnya.

\section{b. Metode Pengumpulan Data}

1) Studi Literatur

Studi literature dilakukan dengan cara menghimpun informasi relevan topik yang menjadi objek penelitian dari buku-buku, karya ilmiah, tesis, disertasi, dan jurnal. Lalu data yang berhasil dikumpulkan akan menjadi pembahasan dengan dianalisis dan dijelaskan untuk menemukan titik terangnya.

2) Dokumentasi

Dokumentasi dilakukan dengan cara menganalisis data-data yang mana mencari fakta dalam data yang tersimpan.

\section{c. Metode Perancangan Sistem}

Sistem perancangan menggunakan metode prototyping, yang mana pengertiannya adalah metode pengembangan sistem informasi sebelum dibuat produksi massal untuk dipasarkan dan dalam skala sebanarbenarnya.

Menurut[6], tahapan yang harus dilakukan dalam metode prototype, adalah sebagai berikut :

1) Mengumpulkan kebutuhan

Disini baik konsumen dan pengembang harus bersama-sama mengidentifikasi kebutuhan, mencari garis besar apa dalam system yang akan dibuat.

2) Mulai Membangun Prototyping

Dengan cara merancang sederhana yang mana fokusnya pada design output untuk disajikan kepada konsumen. Contoh dalam pembuatannya adalah membuat beranda, format input dan format output).

3) Pengevaluasian Prototyping

Konsumen akan melakukan evaluasi yang mencakup apakah prototyping ini sudah sudah sesuai dengan keinginan dan kebutuhan oleh konsumen. Jika tidak, maka perlu adanya 
berbalik pada langkah 1-2 dan memperbaikinya. Jika sudah maka lanjut pada langkah 4.

4) Pengkodean Sistem

Metode prototyping akan mulai diterjemahkan ke Bahasa pemrograman yang tepat.

5) Menguji Sistem Prototyping

Memasuki sistem yang sudah jadi dalam bentuk perangkat lunak, maka harus diuji sebelum digunakan.

6) Evaluasi Sistem Prototyping

Adanya evalauasi yang setelah mengetahui kelemahan dari pengujian yang dilakukan.

7) Penggunaan Sistem

Setelah melewati proses yang panjang, sistem yang sudah sempurna akan digunakan.

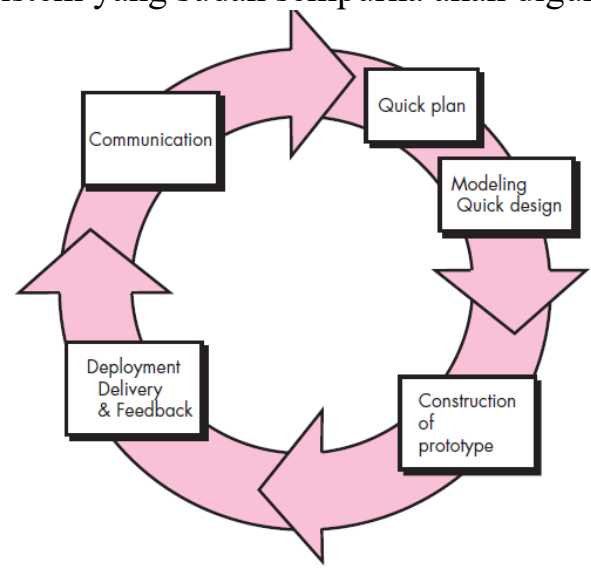

Gambar 1. tahapan metode Prototype

Dari metode prototyping diatas, dalam karya tulid ini dibatasi hanya sampai tahap kedua yaitu Quick Design atau pembuatan desain secara umum.

\section{TINJAUAN PUSTAKA} Berikut penelitian yang pernah
sehubungan dengan

1. Penelitian[4], penyebaran Covid-19 yaitu :

Covid-19 ini menularkan relatif cepat dan untuk tingkat mortalitas tidak bisa diabaikan, oleh karena itu penyakit baru ini menyebabkan pandemi, apalagi belum adanya terapi yang definitif.

2. Penelitian[5], mengemukakan bahwa saat ini masyarakat Indonesia sudah mengalami khawatir yang cukup besar dari adanya Covid-19, sehingga perlu adanya upaya agar memutus mata rantai penyebaran Covid-19, contoh Kebijakan Pemerintah untuk Menetapkan Lockdown “.

Maka jika diperhatikan permasalahan tersebut, dengan judul "Inovasi E-Gelang Sebagai Alat Deteksi Dini Untuk Meminimalisasi Penyebaran Covid-19". Karya tulis ini memberikan gagasan tentang penciptaan sebuah alat yang bisa mendeteksi dini Covid-19 pada diri sendiri dan lingkungan sekitar. Inovasi alat yang digagas ini dimaksudkan untuk memutus pelan-pelan rantai penyebaran Covid-19. Pengembangan inovasi e-gelang ini diarahkan untuk mendapat data dan informasi perilaku setiap individu satu dengan lainnya, sehingga perlahan diharapkan setiap orang mampu mengerti dirinya saat ini dan mengerti siapa saja yang terkoneksinya kuat dengan orang lain, lalu selama yang melaporkan tidak terlambat, kepada pemerintah/tim khusus penanggulangan Covid-19.

\section{HASIL DAN PEMBAHASAN \\ a. Analisis Penyebaran Covid-19 di Negara Indonesia}

Virus Corona ini mulai heboh berawal dari pasar makanan laut yang ada di Huanan, Kota Wuhan, China. Ada kurang lebih 375 orang di Pasar tersebut yang terinfeksi Virus Corona ini dengan gejala-gejala lemas, demam, batuk kering dan sesak napas[7]. Virus Corona baru ini masih terus merebak di hampir seluruh dunia dengan total kasus sebanyak 3.212.062 pasien positif hingg Kamis, 30 April 2020. Jumlah pasien yang dinyatakan meninggal dunia telah tercatat mencapai 227.784 dengan total pasien berhasil sembuh terbilang 998.007 orang. Episentrum COVID-19 paling tinggi secara global masih ditempati Amerika Serikat (AS) dengan kasus sejumlah 1.35 .765 orang [8]. Data terbaru virus Corona di Indonesia telah diumumkan yaitu. 1.522 sembuh, dan 792 meninggal [9].

Semakin lama semakin naik angka yang terdeteksi Positif Covid19. Sudah sejak pertengahan Maret 2020 pemerintah Indonesia menerapkan sosial distancing sebagai upaya mencegahnya, namun sayangnya semakin lama masyarakat juga jenuh. Meski protokol kesehatan selalu digalakkan, jalan sudah makin ramai, banyak orang yang tidak sadar apakah dirinya terpapar atau tidak. Alhasil 
grafik yang terpapar positif corona terus melambung. Pemerintah selalu berusaha untuk menghimbau masyarakarnya untuk tetap berjaga-jaga meski tidak sedang dirumah.

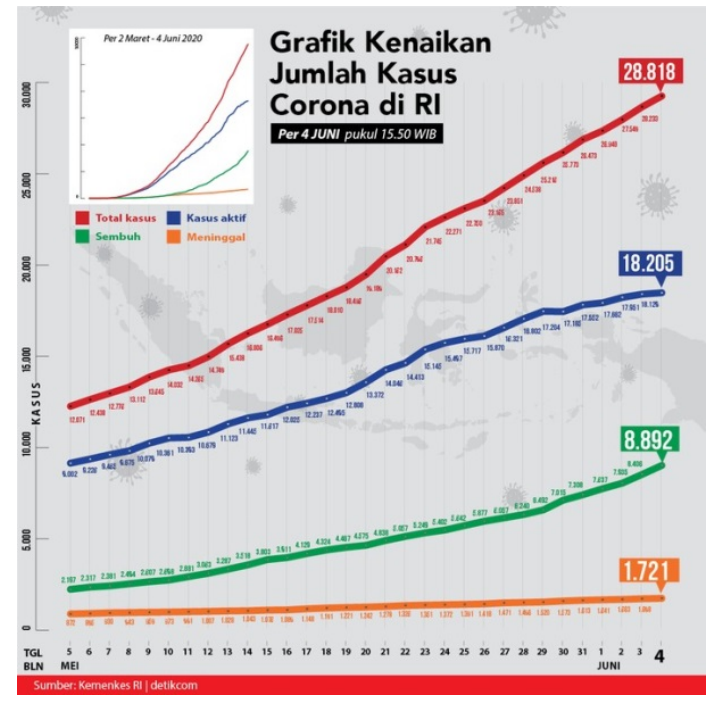

Gambar 2 Grafik kasus corona di Indonesia Sumber : Infografis detikcom

\section{b. Potensi Penggunaan E-Gelang Sebagai Alat Pendeteksi Dini Covid-19}

Adanya pandemi yang melanda saat ini, sementara aktivitas manusia yang terpaksa tetap berjalan karena tidak bisa WFH, teknologi bisa membantu sangat signifikan untuk upaya pencegahan Covid-19, salah satunya adalah penulisan gagasan di karya tulis ini yaitu pembuatan gelang sebagai pendeteksi awal Covid19. Pelaksanaan gagasan ini memerlukan dukungan dan respon dari pemerintah. Perancangan juga harus didampingi dan diarahkan oleh ahli teknologi informasi, lalu akan di uji coba pada masyarakat, setelah itu evaluasi, dan terakhir harus diadakan perbaikan sampai pada akhirnya layak untuk dipasarkan.

\section{c. Penciptaan E-Gelang Sebagai Alat Pendeteksi Covid-19}

Ide dalam membuat dan merancang egelang ini adalah gagasan penulis sebagai alternatif dan strategi dalam meminimalkan penyebaran Covid-19. Alat pendeteksi yang dipilih adalah menciptakan gelang, karena bisa dipakai untuk semua kalangan, bisa untuk semua gender, dan untuk anak-anak gelang ini bisa dirancang berdasarkan besar tangan ratarata anak berumur 7-13 tahun. Karena akan cukup besar jika memakai sama dengan dewasa. Jika yang memakai masih tergolong anak-anak, maka ketika regitstrasi bisa untuk yang menginput nomor adalah nomor orang tua ke hp orang tuanya, sehingga dari situ, orang tua biasa mengetahui apa dan kemana jika si anak pergi.

Dirancang dengan komponen pendukung untuk mendapat informasinya, yaitu ada 6 komponen diantaranya.

1) Tombol on/off: fungsi dari tombol on off untuk mematikan dan menghidupkan gelang.

2) Tombol skip berfungsi apabila ada bunyi peringatan pemilik bisa klik agar tidak lagi bunyi dan menyadari apa yang harus dilakukan misal menjauh dari keramaian.

3) Lampu LED merah menyala mengindikasikan jika tubuh ini detak jantungnya cepat.

4) Sensor suhu yang diukur adalah suhu badan pemilik.

5) Sensor detak jantung berfungsi mendeteksi kecepatan detak/stabil tidaknya napas dalam jantung, dan 8

6) Sensor jarak berfungsi untuk mengetahui apakah sedang dalam keraaian atau tidak.

Tanda yang diberikan oleh gelang ini jika jarak kita kurang dari 2 meter maka akan bunyi alarm dalam gelang, jika suhu tubuh diatas 37 akan juga bunyi alarmnya, dan jika napas/denyut jantung kita diketahui tidak stabil dalam jantung maka output nya lampu LED akan menyala merah.

Hasil yang diharapkan adalah orang menjadi paham dengan keadaan mereka dan menjadi peduli untuk sesama, gelang ini disambungkan dengan penggunaan aplikasi di handphone melalui aplikasi yang sudah terhubung dengan gelang itu. Interface atau tampilan sederhana yang meliputi menunya adalah sebagai berikut.

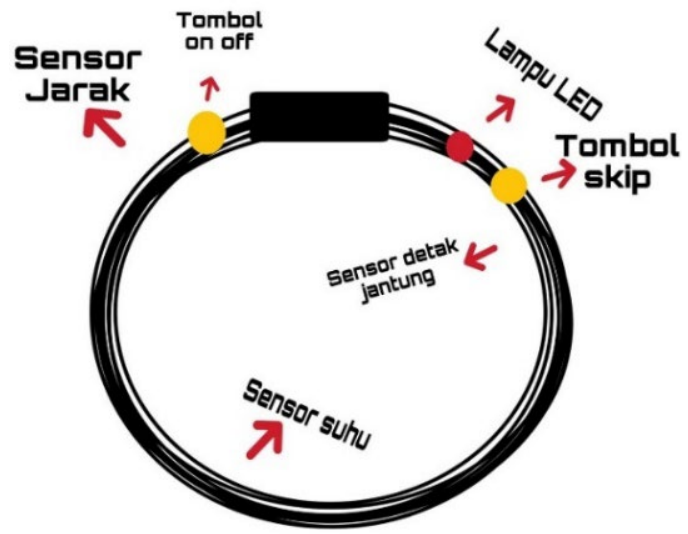


Gambar 3. Sketsa Gelang Sebagai Alat Pendeteksi

\section{KESIMPULAN DAN SARAN \\ a. Kesimpulan}

Pada penelitian mengenai Inovasi EGelang Sebagai Alat Deteksi Dini Untuk Meminimalisasi Penyebaran Covid-19, maka dapat disimpulkan sebagai berikut :

a. Covid-19 adalah penyakit baru dari Virus Corona yang membuat heboh seluruh dunia dan menyebabkan pandemik di seluruh dunia.

b. Gejala ringan Covid-19 adalah demam, batuk, tenggorokan kering, dan sesak napas. Cara pencegahannya dengan memakai masker, rajin mencuci tangan, membawa handsanitazer, menjaga kebersihan menaati protokol kesehatan.

c. Gagasan inovasi penciptaan e-gelang ini sebagai alat pendeteksi dini gejala Covid19 yang mana bisa mengukur suhu tubuh, jarak, dan detak jantung sebagai acuan untuk mendeteksi dari dalam diri dahulu.

d. Tujuan dariadanya inovasi e-gelang ini adalah mengidentifikasi dan mengembankan konsep perancangan egelang, dan menganalisis korelasi egelang jika di connect kan dengan aplikasi yang ada di smartphone dalam upaya penciptaan alat deteksi dini Covid19.

\section{REFERENSI}

alodokter.com.(2020). COVID-19 Gejala, penyebab, dan cara mengobati.https://www.alodokter.c om/covid-19. Diakses 22 Juli 2020 .

detik.com.(2020). Kapan Sebenarnya Corona Pertama Kali Masuk RI?. https://news.detik.com/berita/d4991485/kapan-sebenarnya-coronapertama-kali-masuk-ri/1. Diakses 21 Juli 2020.

Tirto.id.(2020). Update Corona 29 April 2020 Indonesia \& Dunia: Data Kasus Hari Ini. https://tirto.id/update-corona29-april-2020-indonesia-dunia-datakasus-hari-ini-feSL. Diakses 19 Agustus 2020.
Susilo, Adityo dkk. (2020). Coronavirus Disease 2019: Tinjauan Literatur Terkini. Jurnal Penyakit Dalam, Vol 7. 45-67.

Nur dan Annisa.(2020). Kebijakan Pemberlakuan Lockdown Sebagai Antisipasi Penyebaran Corona Virus Covid-19*. Salam: Jurnal Sosial dan Budaya Syar-i. Vol 7. 227-238.

Suhendri, Redi. (2017). Metodologi Penelitian.https://sites.google.com/a/st udent.unsika.ac.id/metodologi_penelit ian redisuhendri113/tugas-1-5metode-rpl/prototyping-model. Diaksses pada 25 Juli 2020.

Supardi, Ahmad dan Rahmadi Rahmad. (2020). Virus Corona, Mewabah di Wuhan Menyebar Cepat Ke Penjuru Dunia.https://www.mongabay.co.id/2 020/01/28/virus-corona-mewabah-diwuhan-menyebar-cepat-ke-penjurudunia/. Diakses 25 Juli 2020.

Al-Qodariah, Farida. (2020). Update Virus Corona di Dunia. per Kamis, 30 April 2020: Total Kasus Turki Tertinggi SeAsia. https://www.pikiranrakyat.com/internasional/pr01373998/update-virus-corona-didunia-per-kamis-30-april-2020-totalkasus-turki-tertinggi-se-asia. Diakses 27 Juli 2020.

Pramudiarja, AN Uyung. (2020). Update Corona di Indonesia 30 April : Positif 1.522, $792 \quad$ Meninggal. https://health.detik.com/beritadetikhealth/d-4997529/update-coronadi-indonesia-30-april-10118-positif1522-sembuh-792-meninggal. Diakses 29 Juli 2020. 